\title{
Alkaline activation of high-calcium ash and iron ore tailings and their recycling potential in building materials
}

\author{
Ativação alcalina de cinzas com alto teor de cálcio e \\ rejeito de minério de ferro e seu potencial de reciclagem \\ para utilização como material de construção
}

\author{
Augusto Cesar da Silva Bezerra \\ Sâmara França \\ Luciano Fernandes de Magalhães \\ Maria Cristina Ramos de Carvalho
}

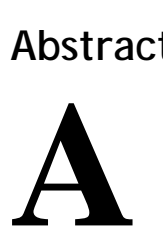

lkali-activated materials are agglomerates obtained from the alkaline activation of aluminum- and silicone-rich precursors. The most popular precursors for this type of activation are low-calcium fly ashes, blast furnace slag, and metakaolin. However, both high-calcium ashes (HCAs) and iron ore tailings (IOTs) are interesting wastes that can be investigated as precursors because of their available volume and environmental impact during their final deposition. Therefore, by performing tests of compressive strength, FTIR spectrometry and scanning electron microscopy, we sought to identify the products formed during HCA and IOT activation without thermal treatment. Nine mortar formulations with different HCA and IOT proportions were developed using sodium hydroxide and sodium silicate as activators. Thus, using FTIR spectrometry, we observed the reaction between the industrial wastes. Additionally, the compressive strength result suggested that the material could be used as compressed blocks in masonry walls for the development of more environmentally friendly building materials, which would mitigate the impact of waste disposal and convert industrial solid waste into value-added products.

Keywords: Alkaline activation. High-calcium ash. Iron ore tailings. Compressed blocks. Waste valorization.

\section{${ }^{1}$ Augusto Cesar da Silva Bezerra ${ }^{1}$ Centro Federal de Educação Tecnológica de Minas Gerais Belo Horizonte - MG - Brasil}

2 Sâmara França ${ }^{2}$ Centro Federal de Educação Tecnológica de Minas Gerais Belo Horizonte - MG - Brasil

\section{${ }^{3}$ Luciano Fernandes de}

Magalhães

${ }^{3}$ Centro Federal de Educação Tecnológica de Minas Gerais Belo Horizonte - MG - Brasil

\section{${ }^{4}$ Maria Cristina Ramos de}

Carvalho

${ }^{4}$ Centro Federal de Educação Tecnológica de Minas Gerais Belo Horizonte - MG - Brasil

Recebido em 24/06/18 Aceito em 28/10/18

\section{Resumo}

Materiais álcali ativados são aglomerantes obtidos a partir da ativação alcalina de precursores ricos em alumínio e silício. Os precursores mais comuns utilizados para ativação são as cinzas com baixo teor de cálcio, as escórias de alto forno e o metacaulim. Contudo, a cinza de cavaco de eucalipto (CCE) e o rejeito de minério de ferro (RMF) são resíduos interessantes para ser estudados como precursores devidoao volume disponível e ao impacto ambiental advindo de sua deposição final. Diante disso, por meio de ensaios de resistência à compressão, espectrometria de FTIR e microscopia eletrônica de varredura buscou-se identificar os produtos formados pela ativação alcalina da CCE e RMF. Para isso foram desenvolvidas nove pastas com proporções diferentes de CCE e RMF, utilizando como ativadores o hidróxido de sódio e o silicato de sódio. Como resultado observou-se pela espectrometria FTIR a reação entre os resíduos industriais. A resistência à compressão sugere que o material álcali ativado pode ser utilizado como blocos compactados para a alvenaria de vedação, de forma a contribuir para o desenvolvimento de materiais mais ecológicos, mitigando os impactos ambientais causados pela disposição e transformando os resíduos sólidos industriais em produtos com valor agregado.

Palavras-chave: Ativação alcalina. Cinzas com alto teor de cálcio. Rejeito de minério de ferro. Blocos compactados. Reciclagem. 


\section{Introduction}

Alkali-activated materials are potential substitutes for Portland cement because of their mechanical properties, durability, and low environmental impact and because they do not emit $\mathrm{CO}_{2}$ during their production. (PACHECO-TORGAL; CASTRO-GOMES; JALALI, 2008; PROVIS, 2018). Such binders are obtained via the polymerization of aluminum- and silicone-rich precursors that are dissolved in highly alkaline solutions (YIP; LUKEY; VAN DEVENTER, 2005; FOUCHAL et al., 2015).

Several authors have stated that alkaline activation products depend on the precursors and activators used (ISMAIL et al., 2014; PROVIS; BERNAL, 2014). Thus, the variability and complexity of the resulting products are still a challenge for researchers (MYERS et al., 2015; PROVIS; PALOMO; SHI, 2015). According to Provis et al. (2015), high-calcium precursors produce calcium aluminosilicate hydrate (C-A-S-H) with a tobermorite-like structure as the main geopolymerization product, whereas precursors with a low calcium content are more likely to form aluminosilicate alkalis (N-A-S-H) that have a high crosslinking density. These geopolymerization products are directly related to the mechanical resistance of the alkali-activated material (PUERTAS et al., 2011; REDDEN; NEITHALATH, 2014). According to Redden and Neithalath (2014), higher alkali concentrations in an activator increases the generation of N-A-S-H. Puertas et al. (2011) concluded that C-A-S-H formed from $\mathrm{NaOH}$ presents a structure similar to $\mathrm{C}-\mathrm{S}-\mathrm{H}$ with tobermorite and chain lengths between 5 and 14 . When the activator is sodium silicate, tobermorite with chain lengths of 11 and 14 also exists.

The main reports on this subject have studied lowcalcium fly ash, iron ore tailings (IOTs), and metakaolin as precursors for alkali-activated materials (PROVIS; BERNAL, 2014). However, high-calcium ashes (HCAs) for use as eucalyptus chip ashes appear to be an interesting waste for investigation because of their volume and chemical composition. According to Myburg et al. (2014) and Larcombe et al. (2015), eucalyptus is the most cultivated wood in the world (i.e., the main reforestation wood) with approximately 20 million hectares planted in more than 100 countries across six continents. However, the steel industry demands large volumes of charcoal and due to social and environmental aspects, it uses reforestation wood for production (GONÇALVES et al., 2014).
According to the work by Amaya et al. (2015), when burning charcoal, approximately $1 \%$ of the material is transformed into ash. Thus, in the 20 million eucalyptus hectares planted, it is estimated that approximately $74 \times 10^{5} \mathrm{t}$ of ash are produced, according to the average Brazilian productivity level; however, the productivity may vary according to the type of soil, climate and spacing between plants (INDÚSTRIA..., 2017).

High-calcium ashes from eucalyptus have already been proven to be viable cementitious materials that can replace Portland cement in proportions up to 15 \% (RESENDE et al., 2014). It is believed that above this replacement content the ash will not behave similar to other ashes, such as sugar cane bagasse or rice husk ashes, because of its low silicon oxide content (PARIS et al., 2016; BEZERRA et al., 2017).

Although wood is a renewable energy source and aids in capturing carbon, $70 \%$ of wood ash is usually disposed of in landfills (CHOWDHURY; MISHRA; SUGANYA, 2015). Ashes treated as waste increase the landfill rate and impose costs on the incinerator, which often renders biomass-based energy production as economically unfeasible (OBURGER et al., 2016). Moreover, wood ashes have a high alkalinity, and depending on the extent of changes in the soil solution chemistry, pronounced changes in soil $\mathrm{pH}$ may also have an undesirable effect that leads to increased leaching of pollutants and nutrients. Additionally, some of the inorganic compounds could become toxic at high concentrations (WIKLUND, 2017). Thus, the EPC (EUROPEAN..., 2002) waste framework (Decision 1666/2002/EC) has set up a hierarchy of waste treatment options, preferring prevention, reuse and recycling over disposal.

IOTs can also be used as a precursor, and it is a waste that is generated by the mining sector (BASTOS et al., 2016). Global iron ore production is 2,230 billion metric tons (Gt) of usable ore and 1,360 billion metric tons of iron content. Global iron ore production in 2016 on a usable-ore basis was led by the countries listed in Table 1, which together accounted for $93.59 \%$ of global production (U.S. GEOLOGICAL..., 2017).

Based on data from global iron ore production (U.S. GEOLOGICAL..., 2017) and the generation of IOTs in China in 2010 (MENG; NI; ZHANG, 2011), it is estimated that 3,360 billion metric tons of IOTs were generated in 2014 around the world. 
Table 1 - Iron ore production in $\mathbf{2 0 1 6}$

\begin{tabular}{l|c}
\hline \multicolumn{1}{c|}{ Country } & Production (Gt) \\
\hline Australia & 825 \\
Brazil & 391 \\
China & 353 \\
India & 160 \\
Russia & 100 \\
South Africa & 60 \\
Ukraine & 58 \\
Canada & 48 \\
United States & 41 \\
Iran & 26 \\
Sweden & 25 \\
\hline
\end{tabular}

IOTs are usually disposed of as a dam (BASTOS et al., 2016; PAPPU; SAXENA; ASOLEKAR, 2007). Dams have a high implementation impact due to their high volume and may cause environmental and social impacts when disruption occurs (PASSOS; COELHO; DIAS, 2017). Thus, the safety of tailing dams is currently a challenge for engineering. Dams are designed to last indefinitely; however, in recent decades, accidents have occurred that have devastated the surrounding ecosystem and victimized hundreds of species (AIRES et al., 2018). In 1998, a dam failure in Aznalcollar, Spain released 2 million $\mathrm{m}^{3}$ of toxic mud into the environment, resulting in the contamination of aquifers and surface water and the death of several aquatic species (DAVIES, 2002). In 2003, a major disaster of this type occurred in the Republic of Macedonia, releasing $100,000 \mathrm{~m}^{3}$ of damaging tailings with heavy metals in the Kamenica River. The height of the tailing flow was approximately 10 meters and the length was $12 \mathrm{~km}$ (VRHOVNIK et al., 2013).

Additionally, mine tailings are generally linked to elevated heavy metals (JUWARKAR; JAMBHULKAR, 2008), a lack of organic matter and nutrients (LANGE et al., 2012), an acidic pH (CHATURVEDI; AHMED; DHAL, 2014), a poor water holding capacity (MOUAZEN et al., 2014), a high bulk density (SAKAI et al., 2008) and a high salinity (LI et al., 2014).

Because of the impact of its deposition, some authors have already studied the reuse of IOT. Zhang, Ahmaris and Zhang (2011) showed that IOTs are a promising construction material if utilized with geopolymerization technology. Bastos et al. (2016) also investigated the potential of IOTs for infrastructure materials when properly stabilized. Recently, concretes and mortars with IOTs were investigated (CARRASCO et al., 2017; SANTANA FILHO, et al., 2017; FONTES et al., 2016; HUANG et al., 2013). Cui et al. (2017) utilized IOTs for autoclaved aerated concrete in
China due to the billions of tons generated there. Additionally, in Australia, Kuranchie et al. (2015) studied IOTs as aggregates in concrete.

Thus, this study aimed to understand the chemical interactions to produce scientific knowledge that could reduce the impact of deposition of these industrial wastes in the future by incorporating them into building materials. Thus, the products formed from the activation of the two wastes without thermal treatment were identified, IOTs and HCAs, and we correlated them with the compressive strength obtained from using different proportions. The phases were identified using FTIR spectrometry and scanning electron microscopy.

\section{Materials and methods}

IOT samples were collected from the pulp filter at the end of the beneficiation process of iron ore. The HCA sample was obtained at the bag filter of boilers used for steam production. The tailings and ashes endured a milling process in the Pulverisette 5 planetary mill, Fritsch, at $300 \mathrm{rpm}$ for $10 \mathrm{~min}$ After milling, the particle size distribution of the tailings and ashes were determined using a laser granulometer, the Cilas 1090 laser particle size analyzer.

The chemical compositions of IOTs and HCAs were determined via a casting method using lithium tetraborate in X-ray fluorescence spectrometers (PANalytical and Axios Fast and Axios models, respectively). The mineralogical composition was determined via X-ray diffraction using an XRD-7000 instrument from Shimadzu at $40 \mathrm{kV}$ and $30 \mathrm{~mA}$ using $\mathrm{Cu}$ radiation. The angular speed was $0.24^{\circ} / \mathrm{min}$, and the scan interval was from $2 \theta=5^{\circ}$ to $80^{\circ}$. To analyze the diffractogram, the demonstrative version of the Match! software and the Crystallography Open Database, revision 204654 from January 2018 was used. 
For specimen molding, Brazilian standard sand, NBR 7214 (ABNT, 2015), was used in mediumfine (\# 50) and fine (\# 100) particle sizes. As activators, we used sodium silicate from Imperial Química with a $\mathrm{SiO}_{2} / \mathrm{Na}_{2} \mathrm{O}=2.15$ ratio in solution and $47.19 \%$ of solids and $98 \%$ pure solid sodium hydroxide. Additionally, all mixtures used the superplasticizer additive, Silicon ns high 400, which is based on polycarboxylates modified with stabilized nanosilica at a $\mathrm{pH}$ of $3.0 \pm 1.0$, a specific mass of $1.09+0.02 \mathrm{~g} / \mathrm{cm}^{3}$ and a chloride content of $<0.15 \%$ (SILICON, 2017). Despite the polycarboxylic-ether-based superplasticizer not being efficient for this type of material (LASKAR; BHATTACHARJEE, 2013), the plasticizer was used because of its silica-containing chemical composition that was in the proportion of $2 \%$ of the precursors' mass; the activator/precursor ratio was 0.7. The mortars were developed from these materials as shown in Table 2. Four specimens for each proportion and age were molded, following the recommendations of NBR7215 and ASTM C109/C109 M (ABNT, 1996; AMERICAN..., 2016) standards in cylindrical $25 \times 50 \mathrm{~mm}$ (diameter $\mathrm{x}$ height) PVC molds. Curing occurred at room temperature. The specimens were tested for compression at 7 and 28 days using an EMIC universal testing machine at a $0.25+0.05 \mathrm{MPa} / \mathrm{s}$ loading speed according to the testing recommendations of the NBR7215 standard (ABNT, 1996). Table 3 shows the amount of each activator used and the amount of water required to maintain the same activator/precursor ratio in all mixtures. To obtain insight into the physicochemical behavior of this system, FTIR was used to confirm the existence and formation of the phases during the geopolymerization phase. The infrared spectra were recorded using an IRPrestige 21 from Shimadzu using the $\mathrm{KBr}$ method. For the morphological characterization, fragments of the broken specimen were imaged using a
HITACHI SEM, model TM 3000, with a backscattered electron detector.

For statistical evaluation of the compressive strength results, we used the "Anova: Simple factor" method using Microsoft Excel software and a significance level of $5 \%$. The results of the ANOVA were verified by the hypothesis that the results of the compressive strength of the specimens are exactly equal in the gap, i.e., the results can be considered similar. For the analysis, we took into consideration the source of variation between groups and within groups. For the $\mathrm{P}$ value test, $\mathrm{P}$ values smaller than the degree of significance rejected the equality between the resistors. Another method of analysis was to compare the value of the critical region boundary (critical F) and the value of F (F). If " $F$ " exceeded "critical F", the hypothesis needed to be rejected.

\section{Results}

The chemical compositions of the IOTs and HCAs obtained via XRD are shown in Table 4. As shown, the main constituents of the IOTs are $\mathrm{Fe}_{2} \mathrm{O}_{3}(65.78 \%), \mathrm{SiO}_{2}$ (22.3\%), and $\mathrm{Al}_{2} \mathrm{O}_{3}$ (4.25 $\%)$. Other components appear in quantities below 1 \%. HCA is chemically composed mostly of $\mathrm{CaO}$ (43.1 \%), $\mathrm{MgO}$ (8.24 \%), $\mathrm{Al}_{2} \mathrm{O}_{3}$ (4.94\%), $\mathrm{K}_{2} \mathrm{O}$ (4.52 \%), $\mathrm{P}_{2} \mathrm{O}_{5}$ (3.24 \%), and $\mathrm{Fe}_{2} \mathrm{O}_{3}$ (2.42 \%). The HCA showed a loss on ignition of $29.66 \%$, and much of this loss may be due to the high carbon content of HCA. This loss on ignition is higher than that reported in the literature (PARIS et al., 2016), and because the HCA is originated from biomass, it contributes even more to the capture and removal of $\mathrm{CO}_{2}$ mentioned above (ZHAO, 2018; ROGELJ et al., 2016). The main minerals present in the IOTs and HCAs, as shown in Figure 1 , were identified in the diffractogram as showed in Table 5.

Table 2 - Material Ratios

\begin{tabular}{c|c|c|c|c|c}
\hline Mortars & $\begin{array}{c}\text { HCA } \\
(\%)\end{array}$ & $\begin{array}{c}\text { IOT } \\
(\%)\end{array}$ & $\mathbf{S i O}_{2} / \mathbf{N a}_{2} \mathbf{O}$ & Activator/precursor & Plasticizer \\
\hline HCA70 IOT30 SN1.00 & 70 & 30 & \multirow{2}{*}{1.00} & & \\
HCA50 IOT50 SN1.00 & 50 & 50 & & & \\
HCA30 IOT70 SN1.00 & 30 & 70 & & \multirow{2}{*}{0.7} & 2 \% mass of \\
HCA70 IOT30 SN1.55 & 70 & 30 & \multirow{2}{*}{1.55} & & \\
HCA50 IOT50 SN1.55 & 50 & 50 & & & \\
HCA30 IOT70 SN1.55 & 30 & 70 & & & \\
\hline HCA70 IOT30 SN1.85 & 70 & 30 & \multirow{2}{*}{1.85} & & \\
HCA50 IOT50 SN1.85 & 50 & 50 & & & \\
HCA30 IOT70 SN1.85 & 30 & 70 & & & \\
\hline
\end{tabular}

102 Bezerra, A. C. S.; França, S.; Magalhães, L. F.; Carvalho, M. C. R. 
Table 3 - Activator ratio

\begin{tabular}{|c|c|c|c|c|c|c|}
\hline $\mathrm{SiO}_{2} / \mathrm{Na}_{2} \mathrm{O}$ & $\begin{array}{c}\text { IOT+HCA } \\
\text { (g) }\end{array}$ & $\begin{array}{c}\mathrm{SiO}_{2} \mathrm{Na}_{2} \mathrm{O} \\
\text { (g) }\end{array}$ & $\begin{array}{l}\mathrm{Na}(\mathrm{OH}) \\
\text { (g) }\end{array}$ & $\begin{array}{l}\text { Water } \\
\text { (g) }\end{array}$ & $\begin{array}{c}\text { Water/activator } \\
\text { (g) }\end{array}$ & $\begin{array}{l}\text { Activator/ } \\
\text { precursor }\end{array}$ \\
\hline 1.00 & \multirow{3}{*}{80.00} & 10.00 & 2.25 & 43.75 & 3.57 & \multirow{3}{*}{0.70} \\
\hline 1.55 & & 18.12 & 1.37 & 36.51 & 1.87 & \\
\hline 1.85 & & 21.00 & 0.67 & 34.33 & 1.58 & \\
\hline
\end{tabular}

Table 4 - Chemical composition

\begin{tabular}{c|c|c|c|c|c|c|c|c|c|c|c}
\hline Material & $\mathrm{SiO}_{2}$ & $\mathrm{Al}_{2} \mathbf{O}_{3}$ & $\mathbf{F e}_{2} \mathbf{O}_{3}$ & $\mathbf{C a O}$ & $\mathbf{M g O}$ & $\mathbf{T i O}_{2}$ & $\mathrm{Na}_{2} \mathbf{O}$ & $\mathbf{K}_{2} \mathbf{O}$ & $\mathbf{P}_{2} \mathbf{O}_{5}$ & $\mathbf{M n O}$ & $\mathbf{L O I}$ \\
\hline IOT & 22.30 & 4.25 & 65.78 & 0.01 & 0.14 & 0.21 & $<0.10$ & 0.04 & 0.15 & 0.50 & 6.10 \\
HCA & 1.75 & 4.94 & 2.42 & 43.10 & 8.24 & 0.50 & 0.28 & 4.52 & 3.24 & 0.39 & 29.66 \\
\hline
\end{tabular}

Figure 1 - Diffractogram of (a) IOTs and (b) HCA

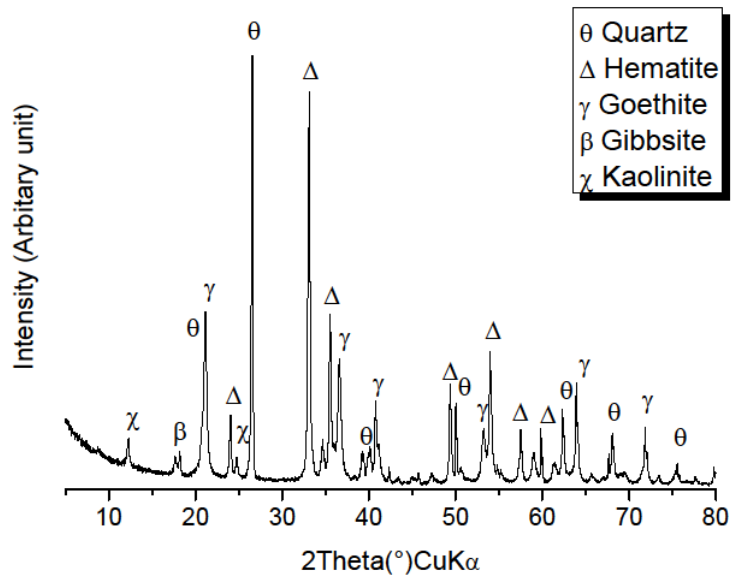

(a)

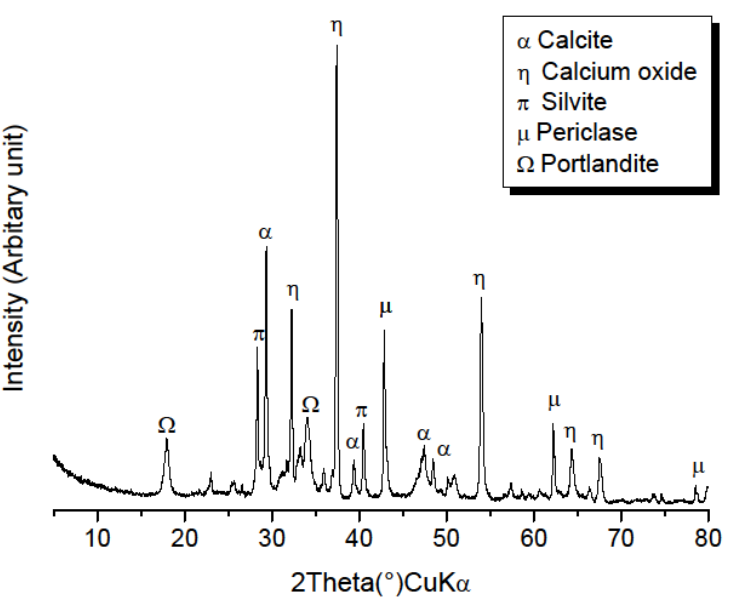

(b)

Table 5 - Chemical composition

\begin{tabular}{l|l}
\hline \multicolumn{1}{c|}{ IOT } & \multicolumn{1}{c}{ HCA } \\
\hline quartz $\left(\mathrm{SiO}_{2}\right)(\operatorname{cod} 9005019)$ & calcite $\left(\mathrm{CaCO}_{3}\right)(\operatorname{cod} 1010962)$, \\
hematite $\left(\mathrm{Fe}_{2} \mathrm{O}_{3}\right)(\operatorname{cod} 9000139)$ & calcium oxide $(\mathrm{CaO})(\operatorname{cod} 1011095)$ \\
goethite $(\mathrm{FeOOH})(\operatorname{cod} 2211652)$ & sylvite $(\mathrm{KCl})(\operatorname{cod} 1000050)$ \\
gibbsite $\left(\mathrm{Al}(\mathrm{OH})_{3}\right)(\operatorname{cod} 1200016)$ & periclase $(\mathrm{MgO})(\operatorname{cod} 9006747)$ \\
kaolinite $\left(\mathrm{Al}_{2} \mathrm{Si}_{2} \mathrm{O}_{5}(\mathrm{OH})_{4}\right)(\operatorname{cod} 9009230)$ & portlandite $\left(\mathrm{Ca}(\mathrm{OH})_{2}\right)(\operatorname{cod} 9000113)$ \\
\hline
\end{tabular}

The main minerals present in the IOTs and HCAs, as shown in Figure 1, were identified in the diffractogram as showed in Table 5.

The FTIR spectra of the industrial wastes are shown in Figure 2 and Figure 3. As shown in the IOTs, the band at $3650 \mathrm{~cm}-1$ corresponds to kaolinite (DICK et al., 2008), the band at 3150 cm-1 corresponds to goethite (WECKLER; LUTZ, 1998), the bands in the range of $800-1200 \mathrm{~cm}-1$ correspond to vibrations of $\mathrm{Si}-\mathrm{O}$ bonds (DICK et al., 2008), and the band at $530 \mathrm{~cm}-1$ corresponds to hematite (YANG et al., 2010).

For the HCAs, in Figure 3, the band at $3640 \mathrm{~cm}-1$ corresponds to portlandite (HORGNIES; WILLIEME; GABET, 2011), the bands at 1400 and $880 \mathrm{~cm}-1$ correspond to calcite (HORGNIES; WILLIEME; GABET, 2011), and $1100 \mathrm{~cm}-1$ corresponds to vibrations of $\mathrm{Si}-\mathrm{O}$ bonds (PALOMO et al., 2007).

As shown in Figure 4, most (i.e., 90 \%) of the IOT and HCA samples had particles with diameters less than $36.63 \mu \mathrm{m}$ and $25.03 \mu \mathrm{m}$, respectively. The average particle diameters obtained in the test were $14.13 \mu \mathrm{m}$ for the tailings and $12.30 \mu \mathrm{m}$ for the ashes.

The results of the compressive strength tests are shown in Figure 5. The mortar with the higher compressive strength at 7 days was HCA70IOT30SN1.85, but the result was quite close for all mixtures with 1.85 and 1.55 
$\mathrm{SiO}_{2} / \mathrm{Na}_{2} \mathrm{O}$ ratios. At 28 days, there was an increase in the strength, and the mixtures with 1.85 and 1.55 ratios continued to have the best performances. However, the mortar with a 1.00 ratio showed better compressive strength with 30 $\%$ HCA and $70 \%$ IOT. With an increase in the HCA content, the compressive strength of the mixture decreased. The compressive strength for this material is superior to that found by Silva et al. (2015), who also utilized industrial waste and geopolymeric stabilization to make compressed blocks. The minimum value typically recognized for compressive earthen materials is $2 \mathrm{MPa}$ at 28 days (HOUBEN; GUILLAUD, 2008). In fact, international documents regulating compressive earth block masonry construction can be less demanding. For instance, the New Zealand NZS 4298 standard (STANDARDS..., 1998) requires a minimum compressive strength of approximately $1.52 \mathrm{MPa}$. The Spanish standard, UNE 41410 (ASOCIACIÓN..., 2008), follows a similar trend since it requires that the lowest class provided (BTC 1) delivers a normalized compressive strength above 1.3 MPa. Thus, these mixtures can also be used for the production of compressed blocks, contributing to valorization of nonhazardous waste and reducing its deposition impact.

Figure 2 -FTIR of the IOTs

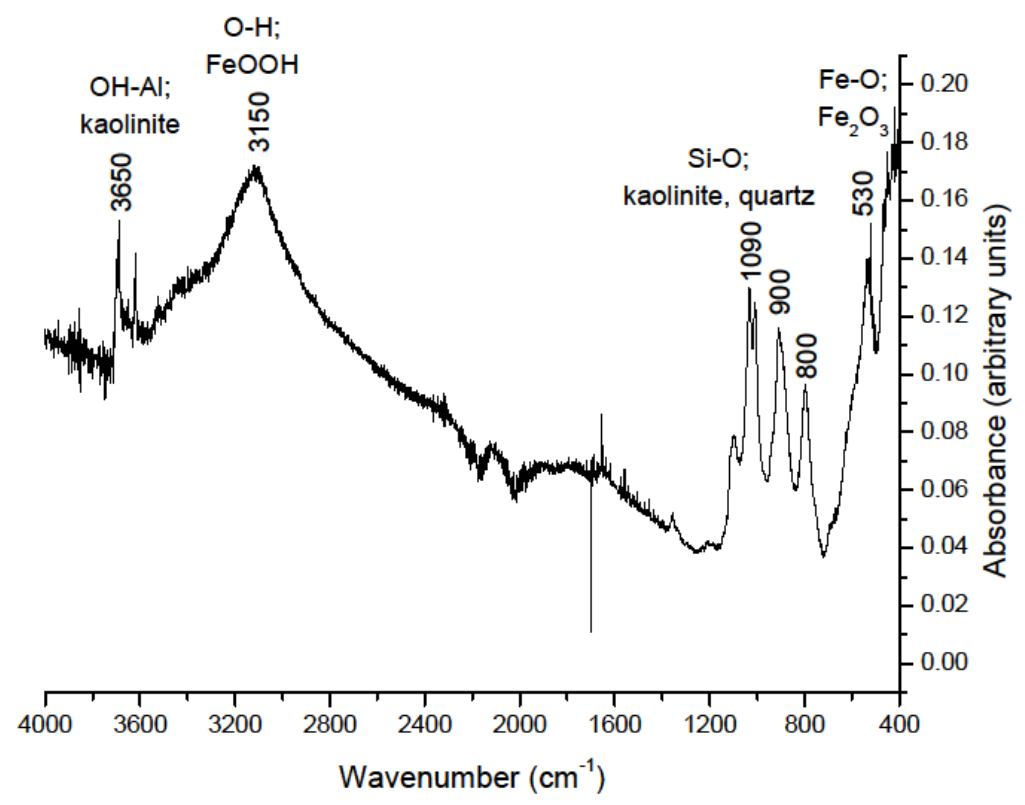

Figure 3 -FTIR of the HCAs

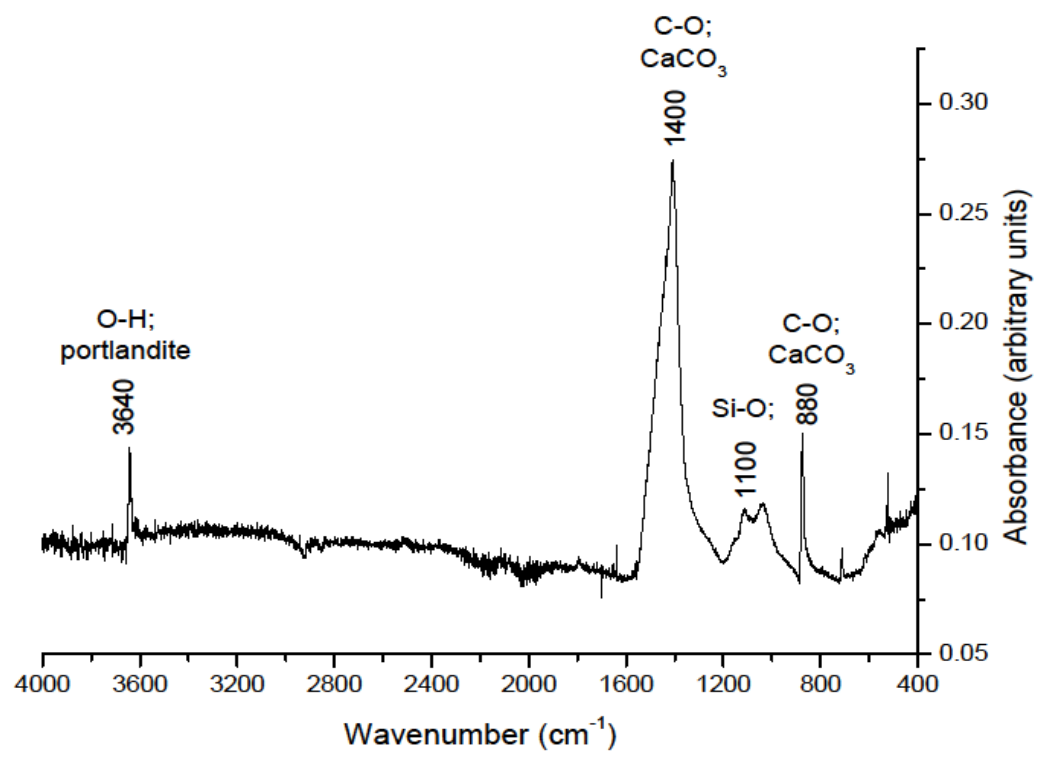

104 Bezerra, A. C. S.; França, S.; Magalhães, L. F.; Carvalho, M. C. R. 
Figure 4 - Diffractogram of (a) IOTs and (b) HCA

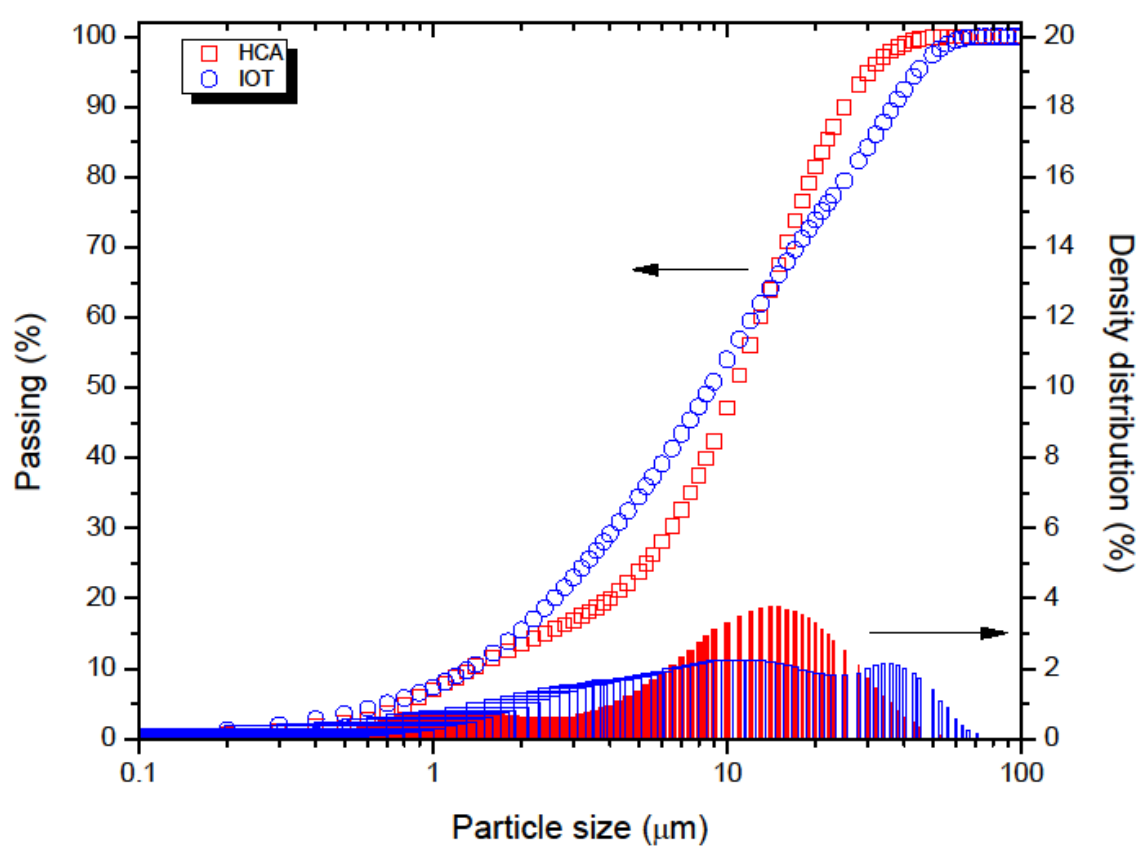

Figure 5 - Compressive strengths

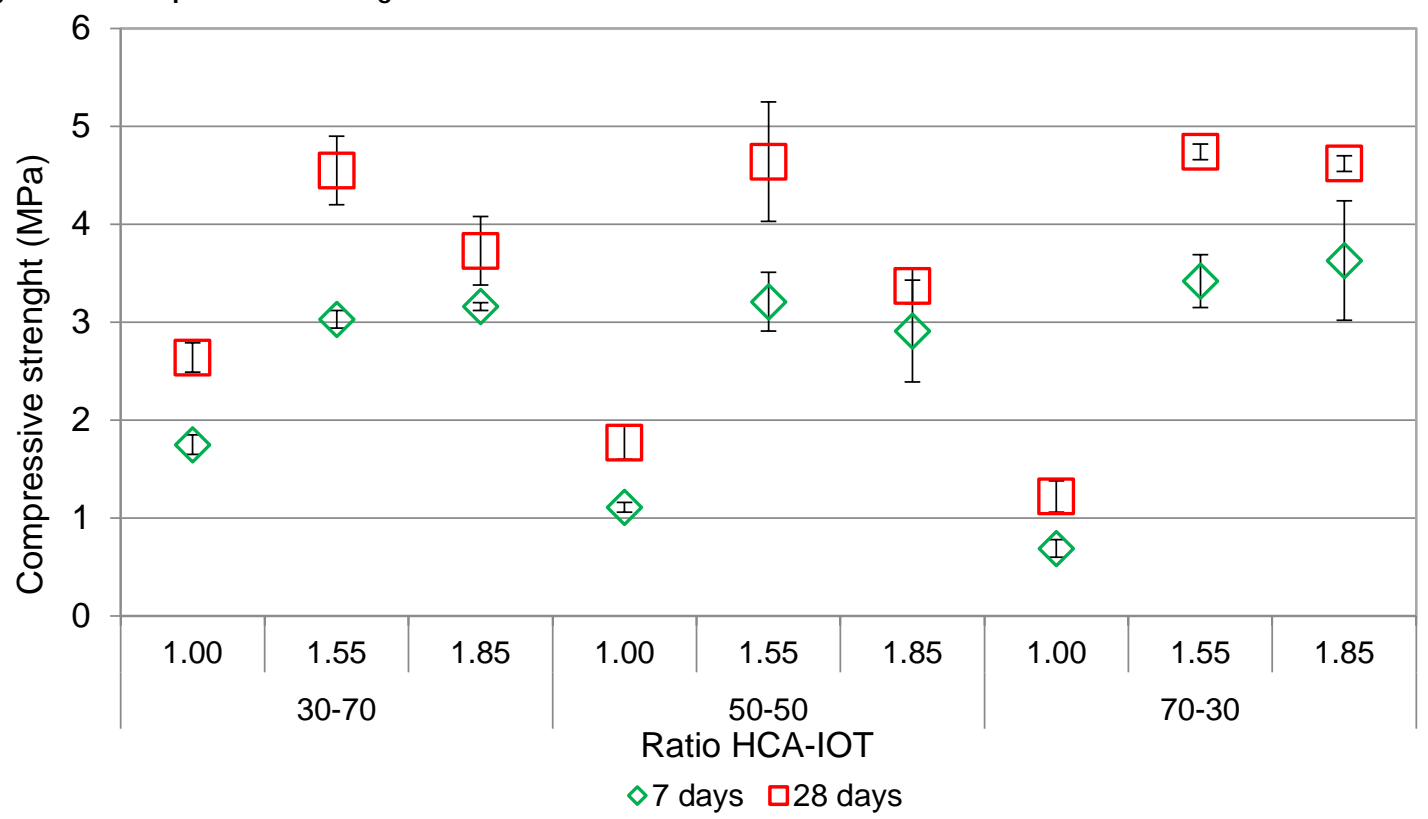

In addition to the geopolymerization, the amount of water present in each mixture contributed directly to the compressive strength. The trace with the highest water content $\left(\mathrm{SiO}_{2} / \mathrm{Na}_{2} \mathrm{O}=1.00\right)$ was the one with the lowest strength. Thus, increasing the water/activator ratio implies an increase in the porosity of the mortar and a reduction in the compressive strength (WINNEFELD et al., 2010).

In the statistical analysis, the averages of the compressive strength tests for the mixtures with $\mathrm{SiO}_{2} / \mathrm{Na}_{2} \mathrm{O}$ ratios of 1.55 and 1.85 were considered similar for both 7 and 28 days, except for the mixture of HCA/IOT at a ratio equal to 50/50 at 28 days. For the average compressive strength of the mixture at a $\mathrm{SiO}_{2} / \mathrm{Na}_{2} \mathrm{O}=1.00$ ratio, the other admixture was not considered statistically similar, without any exception. This could also be supported by the largest amount of water in this mixture since this admixture has over $90 \%$ and $125 \%$ water than those with $\mathrm{SiO}_{2} / \mathrm{Na}_{2} \mathrm{O}=1.55$ and 1.85 ratios, respectively. However, that with the 
$\mathrm{SiO}_{2} / \mathrm{Na}_{2} \mathrm{O} 1.55$ ratio had only $18 \%$ more water than that with the 1.85 ratio.

The FTIR spectra of the mortars show that there was a reaction between the industrial wastes, resulting in the formation of new structures and consumption of others. According to Fig. 6, the mortars with the $1.00 \mathrm{SiO}_{2} / \mathrm{Na}_{2} \mathrm{O}$ ratio maintained the bands for goethite and calcium carbonate, but they have a lower intensity, and the wavenumber that is most expressive is at $1006 \mathrm{~cm}-1$. That wavenumber corresponds to calcium aluminosilicate hydrates and aluminosilicates (KAPELUSZNA et al., 2017), which provide compressive resistance to the material.

In the case of the mortars with 1.55 and 1.85 $\mathrm{SiO}_{2} / \mathrm{Na}_{2} \mathrm{O}$ ratios, shown in Figure 7 and 8, the same bands could be found: goethite (WECKLER; LUTZ, 1998), calcium carbonate (HORGNIES; WILLIEME; GABET, 2011) and calcium aluminosilicate hydrates and aluminosilicates (DICK et al., 2008). However, the mixtures exhibited similar behaviors, which could explain the more homogeneous mechanical performance.

Morphologically, we observed higher IOT percentages in the mortars and the occurrence of crystalline lamellar structures composed of overlapping planes, as shown in Figure 9. This structure can be associated with kaolinite because of its morphology (SILVA FILHO et al., 2015). In higher HCA-content mortars, we found fewer kaolinite-like structures. For the mortars with
$\mathrm{SiO}_{2} / \mathrm{Na}_{2} \mathrm{O}$ ratios between 1.55 and 1.85 , such structures were smaller and more dispersed, as shown in Figure 10. Therefore, the absence of kaolinite in the mortars with a higher HCA content may be associated with the HCA reaction with calcium and thus the development of more resistant structures. Higher levels of calcium oxide result in a higher efficiency of kaolinite dissolution with lower $\mathrm{Na}_{2} \mathrm{O} / \mathrm{SiO}_{2}$ ratios (WHITTINGTON, 1996).

Cube-like structures were found in mortars with $\mathrm{SiO}_{2} / \mathrm{Na}_{2} \mathrm{O}$ ratios between 1.55 and 1.85 , as shown in Figure 11. These structures can be linked to zeolite A because of its morphology (SILVA FILHO et al., 2015) and the increase in the mortars' strength because they have been observed more clearly in formulations that have higher compressive strengths (AYELE et al., 2015). This could also be confirmed by the FTIR spectra in which mortars with the more expressive peaks for aluminosilicates exhibited the best compression strength values, except for mortars with a $\mathrm{SiO}_{2} / \mathrm{Na}_{2} \mathrm{O}$, ratio $=1.00$, which is due to the high amount of water that showed an unsatisfactory behavior for performance as a compressed block.

It is important to highlight that these aluminosilicates structures were formed at room temperature. Tang, Guo and Wang (2013) previously confirmed the interactions between kaolinite and calcium at room temperature, which produce crystalline aluminosilicates.

Figure 6 - FTIR spectra of the mortars with a $1.00 \mathrm{SiO}_{2} / \mathrm{Na}_{2} \mathrm{O}$ ratio

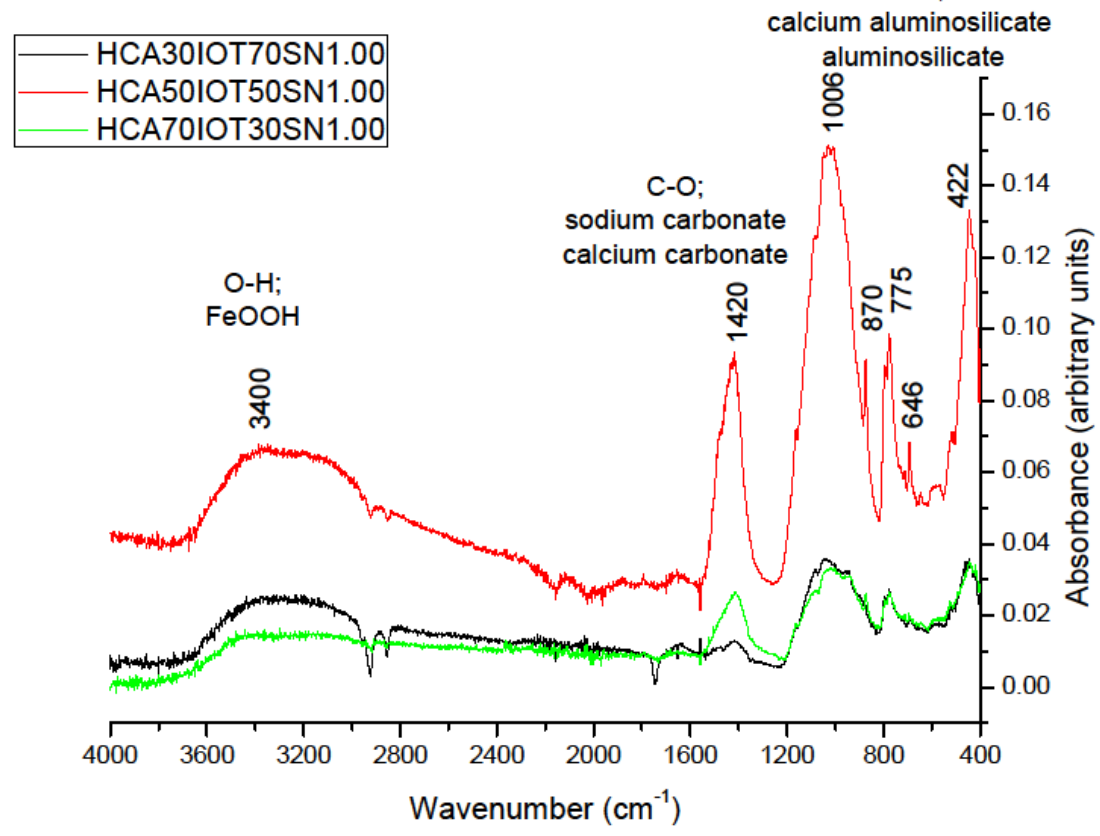

106 Bezerra, A. C. S. ; França, S.; Magalhães, L. F.; Carvalho, M. C. R. 
Figure 7 - FTIR spectra of the mortars with a $1.55 \mathrm{SiO}_{2} / \mathrm{Na}_{2} \mathrm{O}$ ratio

Si-O;

calcium aluminosilicate

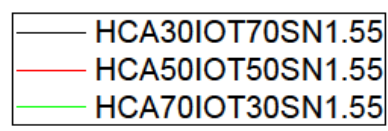
HCA50IOT50SN1.55

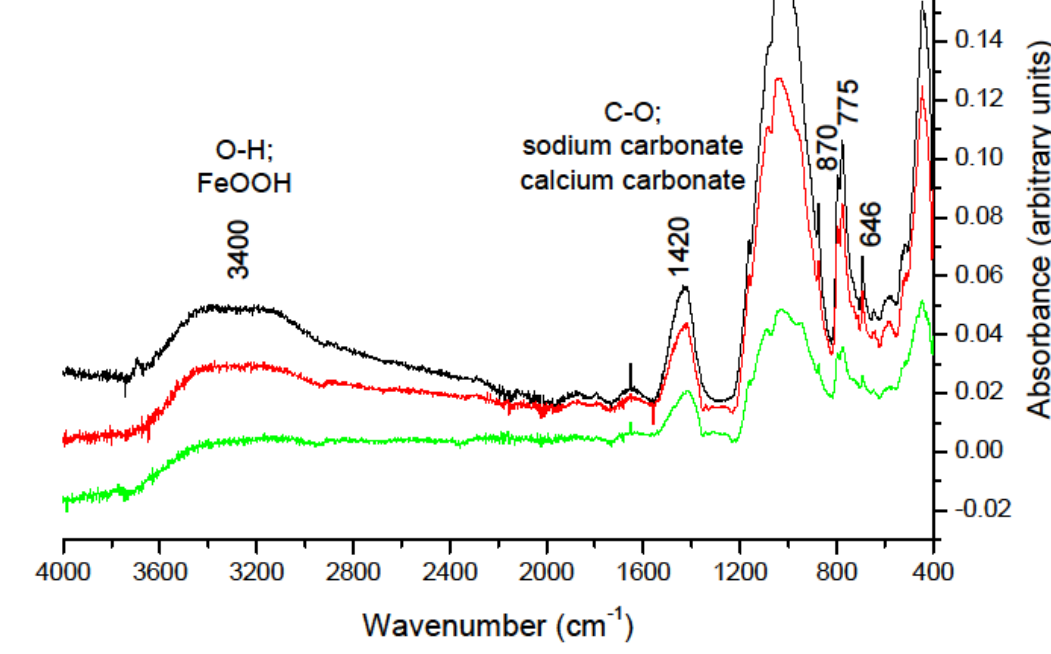

Figure 8 - FTIR spectra of the mortars with a $1.85 \mathrm{SiO}_{2} / \mathrm{Na}_{2} \mathrm{O}$ ratio

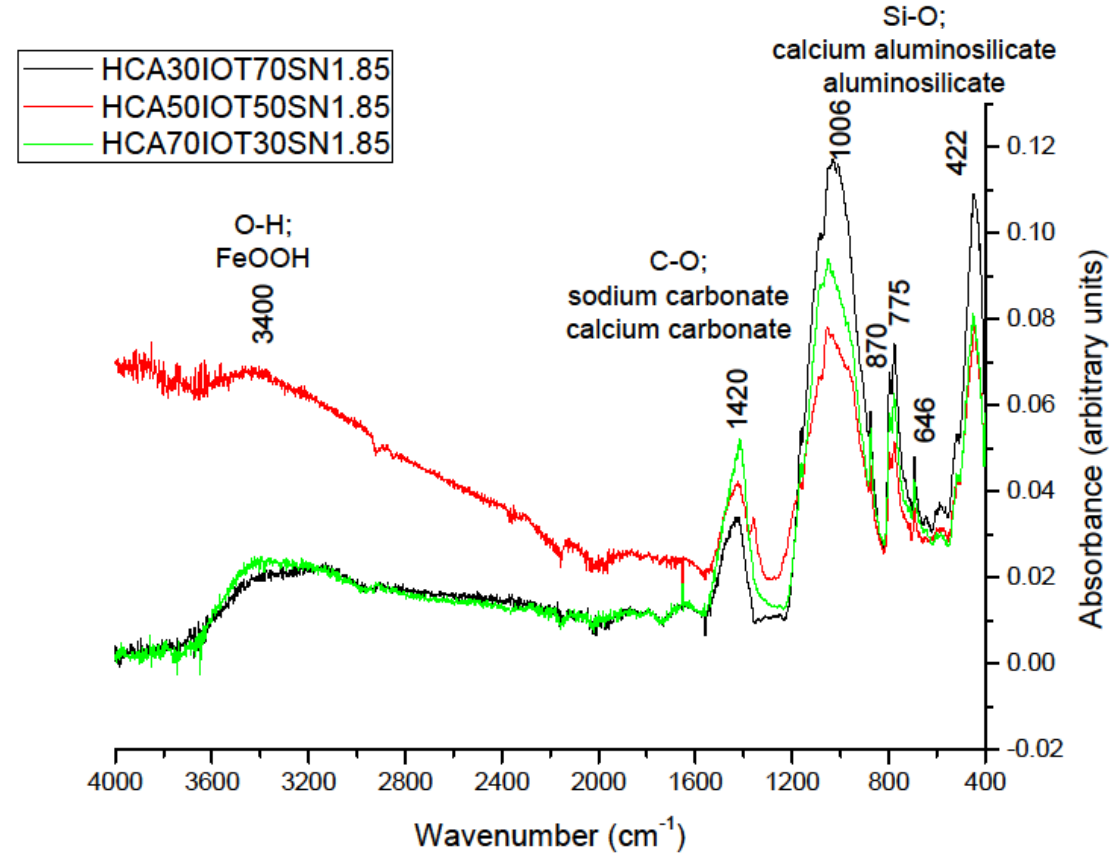


Figure 9 - Kaolinite-like structure of the HCA30IOT70

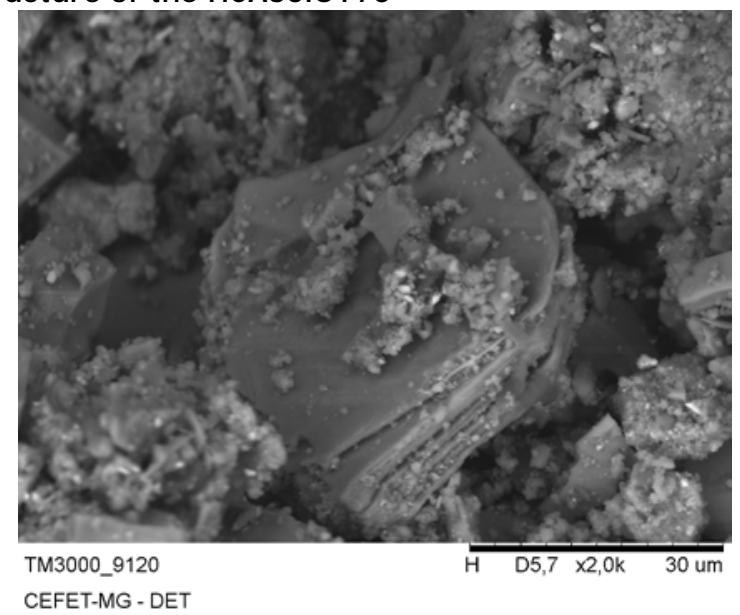

Figure 10 - Micrographs of HCA50IOT50 (a) SN1.55, (b) SN1.85

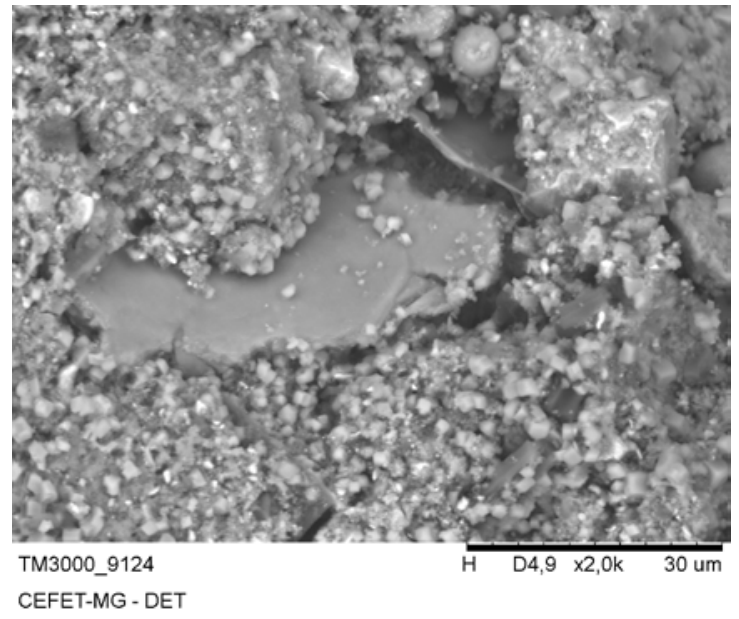

(a)

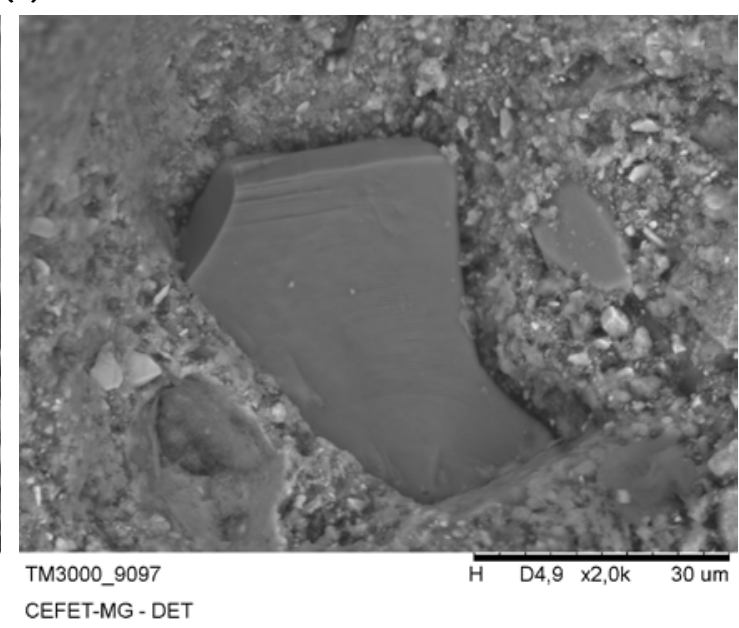

(b)

Figure 11 -Micrograph of the HCA70IOT30SN1.55 mortar

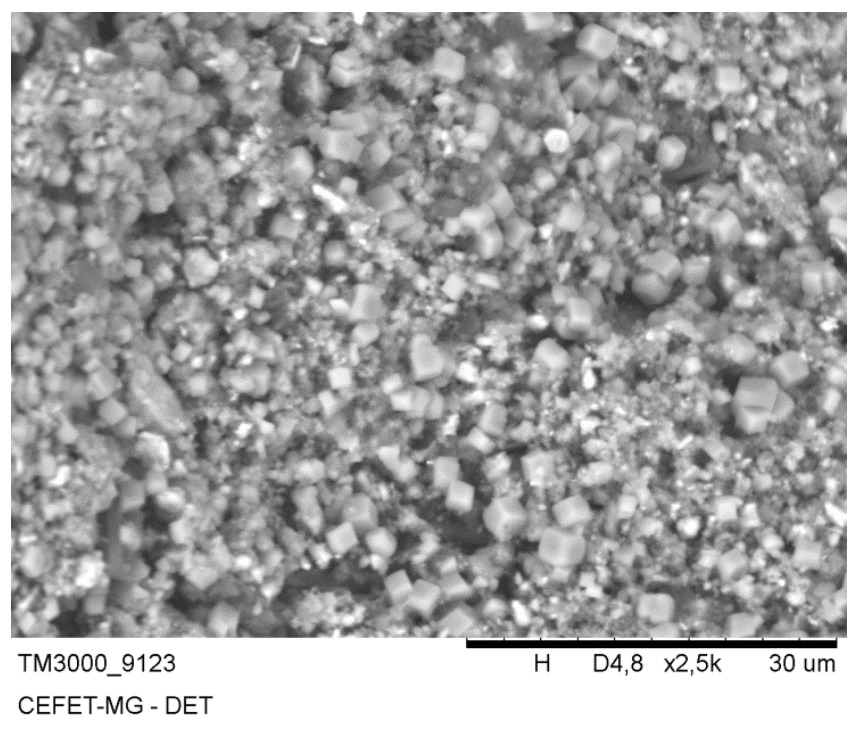

108 Bezerra, A. C. S.; França, S.; Magalhães, L. F.; Carvalho, M. C. R. 


\section{Conclusion}

This study investigated the potential of solid waste alkaline activators as a building material. The results showed that high-calcium ashes and iron ore tailings are potential materials for the development of environmentally friendly building materials. Moreover, when the solid industrial wastes are reused, IOTs will no longer be disposed of in the form of dams and no longer contaminate the soil or subsoil, which is safer for society and the environment. HCAs will no longer be disposed of in landfills, avoiding possible soil $\mathrm{pH}$ changes, its leaching and loss of nutrients that can harm agriculture. Through alkaline activation, the wastes could be stabilized without the use of cement, which contributes to reducing the greenhouse effect.

Using alkaline activation, we observed the reaction between the industrial wastes. The FTIR spectra showed that calcium aluminosilicate is the most expressive phase, which ensures the compressive resistance of the material. Morphologically, the presence of kaolinite was identified as a constituent of IOTs in the mortars. The kaolinite may have reacted with the calcium from the ashes to form the calcium aluminosilicates. Zeolite A was also observed and is an example of aluminosilicate structures identified in the FTIR spectra.

Regarding the compressive strength, all formulations except for that with a $1.00 \mathrm{SiO}_{2} / \mathrm{Na}_{2} \mathrm{O}$ ratio have the potential for application in compacted blocks since the minimum strength for these blocks at 28 days is $2 \mathrm{MPa}$. Furthermore, other aspects need to be assessed in future investigations, such as the non-mechanical features of the masonry system. These include features, such as the acoustic and thermal performance of the masonry walls, the development and study of compatible renderings, and a durability assessment. In addition, for the production of masonry elements, the use of two wastes without thermal processing and one of them originating from biomass and having approximately $30 \%$ of carbon in its constitution will lead to the reduction of the carbon footprint of the constructions that use these elements.

\section{References}

AIRES, U. R. V. et al. Changes in Land Use and Land Cover as a Result of the Failure of a Mining Tailings Dam in Mariana, MG, Brazil. Land Use Policy, v. 70, p. 63-70, 2018.
AMAYA, A. et al. Preparation of Charcoal Pellets from Eucalyptus Wood with Different Binders.

Journal of Energy and Natural Resources, v. 4, n. 2, p. 34, 2015.

\section{AMERICAN SOCIETY FOR TESTING AND}

MATERIALS. C109/C109M-16a: standard test method for compressive strength of hydraulic cement mortars (Using 2-in. or [50-mm] Cube Specimens). West Conshohocken, 2016.

\section{ASOCIACIÓN ESPAÑOLA DE} NORMALIZACIÓN Y CERTIFICACIÓN. UNE 41410: compressed earth blocks for walls: definitions, specifications and testing methods. Spain, 2008.

\section{ASSOCIAÇÃO BRASILEIRA DE NORMAS} TÉCNICAS. NBR 7215: cimento Portland: determinação da resistência à compressão. Rio de Janeiro, 1996.

\section{ASSOCIAÇÃO BRASILEIRA DE NORMAS} TÉCNICAS. NBR7214: areia normal para ensaio de cimento: especificação. Rio de Janeiro, 2015.

AYELE, L. et al. Synthesis of Zeolite A From Ethiopian Kaolin. Microporous and Mesoporous Materials, v. 215, p. 29-36, 2015.

BASTOS, L. A. D. C. et al. Using Iron Ore Tailings From Tailing Dams as Road material. Journal of Materials in Civil Engineering, v. 28, n. 10, p. 04016102, 2016.

BEZERRA, A. C. S. et al. Effect of Partial Replacement with Thermally Processed Sugar Cane Bagasse on the Properties of Mortars. Matéria, Rio de Janeiro, v. 22, n. 1, p. e11785, 2017.

CARRASCO, E. V. M et al. Characterization of Mortars With Iron Ore Tailings Using Destructive and Nondestructive Tests. Construction and Building Materials, v. 131, p. 31-38, 2017.

CHATURVEDI, N.; AHMED, M. J.; DHAL, N. K. Effects of Iron ore Tailings on Growth and Physiological Activities of Tagetes Patula L. Journal of soils and sediments, v. 14, n. 4, p. 721-730, 2014.

CHOWDHURY, S.; MISHRA, M.; SUGANYA, O. M. The Incorporation of Wood Waste Ash as a Partial Cement Replacement Material for Making Structural Grade Concrete: an overview. Ain Shams Engineering Journal, v. 6, n. 2, p. 429437, 2015. 
CUI, X. W. et al. Studiul Mecanismului de Reactie în Betonul Celular Autoclavizat cu Continut de Deseuri de Minereu cu Fier/Study on the Reaction Mechanism of Autoclaved Aerated Concrete Based on Iron Ore Tailings. Revista Romana de Materiale, v. 47, n. 1, p. 46-53, 2017.

DAVIES, M. P. Tailings Impoundment Failures: are geotechnical engineers listening. Geotechnical News, v. 20, n. 3, p. 31-36, 2002.

DICK, D. P. et al. Impact of Burning on Soil Chemical Attributes and Organic Matter Composition and on Vegetation. Pesquisa Agropecuária Brasileira, v. 43, n. 5, p. 633-640, 2008.

\section{EUROPEAN PARLIAMENT AND THE}

COUNCIL. Decision no 1666/2002/EC. Sixth Community Environment Action Programme. Official Journal of the European Communities, 2002.

FONTES, W. C. et al. Mortars for Laying and Coating Produced With Iron Ore Tailings From Tailing Dams. Construction and Building Materials, v. 112, p. 988-999, 2016.

FOUCHAL, F. et al. Experimental Evaluation of Hydric Performances of Masonry Walls Made of Earth Bricks, Geopolymer and Wooden Frame. Building and Environment, v. 87, p. 234-243, 2015.

GONÇALVES, T. A. P. et al. A Contribution to the Identification of Charcoal Origin in Brazil: Ianatomical characterization of corymbia and eucalyptus. Maderas. Ciencia y Tecnología, v. 16, n. 3, p. 323-336, 2014.

HORGNIES, M.; WILLIEME, P.; GABET, O. Influence of the Surface Properties of Concrete on the Adhesion of Coating: characterization of the interface by peel test and FT-IR spectroscopy. Progress in Organic Coatings, v. 72, n. 3, p. 360379, 2011.

HOUBEN, H.; GUILLAUD, H. Earth

Construction: a comprehensive guide, CRATerre-EAG. London: Intermediate Technology Publication, 2008.

HUANG, R. et al. Development of Green Engineered Cementitious Composites Using Iron Ore Tailings as Aggregates. Construction and Building Materials, v. 44, p. 757-764, 2013.

INDÚSTRIA BRASILEIRA DE ÁRVORES. O Relatório Ibá 2017. Brasília, 2017.

ISMAIL, I. et al. Modification of Phase Evolution in Alkali-Activated Blast Furnace Slag by the Incorporation of Fly Ash. Cement and Concrete Composites, v. 45, p. 125-135, 2014.
JUWARKAR, A. A.; JAMBHULKAR, H. P. Phytoremediation of Coal Mine Spoil Dump Through Integrated Biotechnological Approach. Bioresource Technology, v. 99, n. 11, p. 47324741, 2008.

KAPELUSZNA, E. et al. Incorporation of $\mathrm{Al}$ in CASH Gels with Various $\mathrm{Ca} / \mathrm{Si}$ and $\mathrm{Al} / \mathrm{Si}$ Ratio: microstructural and structural characteristics with DTA/TG, XRD, FTIR and TEM analysis.

Construction and Building Materials, v. 155, p. 643-653, 2017.

KURANCHIE, F. A. et al. Utilisation of Iron Ore Tailings as Aggregates in Concrete. Cogent Engineering, v. 2, n. 1, p. 1083137, 2015.

LANGE, C. A. et al. Effects of Different Soil Ameliorants on Karee Trees (searsia lancea) Growing on Mine Tailings Dump Soil: part I: pot trials. International journal of phytoremediation, v. 14, n. 9, p. 908-924, 2012.

LARCOMBE, M. J. et al. Patterns of Reproductive Isolation in Eucalyptus: a phylogenetic perspective. Molecular Biology and Evolution, v. 32, n. 7, p. 1833-1846, 2015.

LASKAR, A. I.; BHATTACHARJEE, R. Effect of Plasticizer and Superplasticizer on Rheology of Fly-Ash-Based Geopolymer Concrete. ACI materials journal, v. 110, n. 5, 2013.

LI, X. et al. Understanding the Salinity Issue of Coal Mine Spoils in the Context of Salt Cycle. Environmental geochemistry and health, v. 36, n. 3, p. 453-465, 2014.

MENG, Y.; NI, W.; ZHANG, Y. Current State of Ore Tailings Reusing in China. China Mine Engineering, Beijing, v. 39, n. 5, p. 4-9, 2011.

MOUAZEN, A. M. et al. Multiple on-Line Soil Sensors and Data Fusion Approach for Delineation of Water Holding Capacity Zones For Site Specific Irrigation. Soil and Tillage Research, v. 143, p. 95-105, 2014.

MYBURG, A. A. et al. The Genome of Eucalyptus Grandis. Nature, v. 510, n. 7505, p. 356-362, 2014.

MYERS, R. J. et al. The Role of Al in CrossLinking of Alkali: activated slag cements. Journal of the American Ceramic Society, v. 98, n. 3, p. 996-1004, 2015.

OBURGER, E. et al. Environmental Impact Assessment of Wood Ash Utilization in Forest Road Construction and Maintenance: a field study. Science of the Total Environment, v. 544, p. 711-721, 2016. 
PACHECO-TORGAL, F.; CASTRO-GOMES, J.; JALALI, S. Alkali-Activated Binders: a review: part 1: historical background, terminology, reaction mechanisms and hydration products.

Construction and Building Materials, v. 22, n. 7, p. 1305-1314, 2008.

PALOMO, A. et al. OPC-Fly Ash Cementitious Systems: study of gel binders produced during alkaline hydration. Journal of Materials Science, v. 42, n. 9, p. 2958-2966, 2007.

PAPPU, A.; SAXENA, M.; ASOLEKAR, S. R. Solid Wastes Generation in India and Their Recycling Potential in Building Materials.

Building and Environment, v. 42, n. 6, p. 23112320, 2007.

PARIS, J. M. et al. A Review of Waste Products Utilized as Supplements to Portland Cement in Concrete .Journal of Cleaning Production, v. 121, p. 1-18, 2016.

PASSOS, F. L.; COELHO, P.; DIAS, A. (Des) Territórios da Mineração: planejamento territorial a partir do rompimento em Mariana, MG.

Cadernos Metrópole., v. 19, n. 38, p. 269-297, 2017.

PROVIS, J. L. Alkali-Activated Materials. Cement and Concrete Research, v. 114, p. 4048, 2018.

PROVIS, J. L.; BERNAL, S. A. Geopolymers and Related Alkali-Activated Materials. Annual Review of Materials Research, v. 44, p. 299-327, 2014.

PROVIS, J. L.; PALOMO, A.; SHI, C. Advances in Understanding Alkali-Activated Materials.

Cement and Concrete Research, v. 78, p. 110125, 2015.

PUERTAS, F. et al. A Model for the CASH Gel Formed in Alkali-Activated Slag Cements.

Journal of the European Ceramic Society, v. 31, n. 12, p. 2043-2056, 2011.

REDDEN, R.; NEITHALATH, N. Microstructure, Strength, and Moisture Stability of Alkali Activated Glass Powder-Based Binders. Cement and Concrete Composites, v. 45, p. 46-56, 2014.

RESENDE, D. S. et al. Eucalyptus Chip Ashes in Cementitious Composites. Materials Science Forum, v. 775/776, p. 205-209, 2014.

ROGELJ, J. et al. Paris Agreement Climate Proposals Need a Boost to Keep Warming Well Below 2 C. Nature, v. 534, n. 7609, p. 631, 2016.
SAKAI, H. et al. Soil Compaction on Forest Soils from Different Kinds of Tires and Tracks and Possibility of Accurate Estimate. Croatian Journal of Forest Engineering: Journal for Theory and Application of Forestry Engineering, v. 29, n. 1, p. 15-27, 2008.

SANTANA FILHO, J. N. et al. Technical and Environmental Feasibility of Interlocking Concrete Pavers With Iron Ore Tailings From Tailings Dams. Journal of Materials in Civil Engineering, v. 29, p. 04017104-1-04017104-6, 2017.

SILICON, Ind. e Com. Produtos Químicos. Silicon ns High 400. 2017. Available in:

$<$ http://www.silicon.ind.br/wpcontent/themes/silicon/fichatecnicaproduto/nsad/ficha-silicon-aditivo-concreto-altodesempenho-ns-high-400.pdf $>$. Access: 15 mar. 2019.

SILVA FILHO, S. D. et al. Synthesis of Zeolite A Employing Amazon Kaolin Waste. Cerâmica, v. 61, n. 360, p. 409-413, 2015.

SILVA, R. A. M. et al. CEBs Stabilised With Geopolymeric Binders: mechanical performance of dry-stack masonry. In: INTERNATIONAL CONFERENCE ON THE ENVIRONMENTAL AND TECHNICAL IMPLICATIONS OF CONSTRUCTION WITH ALTERNATIVE MATERIALS, 9., 2015. Proceedings... 2015.

STANDARDS NEW ZEALAND. NZS 4298: materials and workmanship for earth buildings. Wellington, 1998.

TANG, J.; GUO, R.; WANG, J. Inhibition of Interaction Between Kaolinite and K2CO3 by Pretreatment Using Calcium Additive. Journal of Thermal Analysis and Calorimetry, v. 114, n. 1, p. 153-160, 2013.

U.S. GEOLOGICAL SURVEY. Mineral Commodity Summaries 2017. 2017. Available in: <https://doi.org/10.3133/70180197>. Access: 7 abr. 2019.

VRHOVNIK, P. et al. The Occurence of Heavy Metals and Metalloids in Surficial Lake Sediments before and after a Tailings Dam Failure. Polish Journal of Environmental Studies, v. 22, n. 5, p. 1525-1538, 2013.

WECKLER, B.; LUTZ, H. D. Lattice Vibration Spectra: part XCV: infrared spectroscopic studies on the iron oxide hydroxides goethite $(\alpha)$, akaganéite $(\beta)$, lepidocrocite $(\gamma)$, and feroxyhite $(\delta)$. European Journal of Solid State and Inorganic Chemistry, v. 35, n. 8-9, p. 531-544, 1998. 
WHITTINGTON, B. I. The Chemistry of $\mathrm{CaO}$ and $\mathrm{Ca}(\mathrm{OH}) 2$ Relating to the Bayer Process.

Hydrometallurgy, v. 43, n. 1, p. 13-35, 1996.

WIKLUND, J. Effects of Wood Ash on Soil

Fertility and Plant Performance in

Southwestern Kenya. Master's Thesis in Soil

Science. Agriculture Programme - Soil and Plant

Sciences. Swedish University of Agricultural

Sciences. Uppsala, 2017.

WINNEFELD, F. et al. Assessment of Phase Formation in Alkali Activated Low and High Calcium Fly Ashes in Building Materials.

Construction and building materials, v. 24, n. 6 , p. 1086-1093, 2010.

YANG, K. et al. Re-Examination of Characteristic FTIR Spectrum of Secondary Layer in Bilayer Oleic Acid-Coated Fe3O4 Nanoparticles. Applied Surface Science, v. 256, n. 10, p. 3093-3097, 2010.
YIP, C. K.; LUKEY, G.; VAN DEVENTER, J. The Coexistence of Geopolymeric Gel and Calcium Silicate Hydrate at the Early Stage of Alkaline Activation. Cement and Concrete Research, v. 35, n. 9, p. 1688-1697, 2005.

ZHANG, L.; AHMARI, S.; ZHANG, J. Synthesis and Characterization of Fly Ash Modified Mine Tailings-Based Geopolymers. Construction and Building Materials, v. 25, n. 9, p. 3773-3781, 2011.

ZHAO, G. Assessment of Potential Biomass Energy Production in China Towards 2030 and 2050. International Journal of Sustainable Energy, v. 37, n. 1, 47-66, 2018.

\section{Acknowledgments}

The authors would like to express their gratitude to the Minas Gerais State Research Foundation (FAPEMIG APQ3739-16), the National Council for Scientific and Technological Development (CNPq), and the Brazilian Federal Agency for the Support and Evaluation of Graduate Education (CAPES) for financial support and scientific initiation scholarships.

Augusto Cesar da Silva Bezerra

Departamento de Engenharia de Transportes | Centro Federal de Educação Tecnológica de Minas Gerais | Av. Amazonas, 5253, Nova Suíssa | Belo Horizonte - MG - Brasil | CEP 30421-169 | Tel.: (31) 3319-7119 | E-mail: augustobezerra@cefetmg.br

\title{
Sâmara França
}

Departamento de Engenharia Civil | Centro Federal de Educação Tecnológica de Minas Gerais | Tel.: (31) 3319-6848 | E-mail: samarafranca@yahoo.com.br

\section{Luciano Fernandes de Magalhães}

Departamento de Engenharia de Materiais | Centro Federal de Educação Tecnológica de Minas Gerais | Tel.: (31) 3319-7155 | E-mail: luciano_fm8@hotmail.com

Maria Cristina Ramos de Carvalho

Departamento de Engenharia Civil | Centro Federal de Educação Tecnológica de Minas Gerais | Tel.: (31) 33196848 | E-mail: mariacristinaramosdecarvalho@gmail.com

\author{
Revista Ambiente Construído \\ Associação Nacional de Tecnologia do Ambiente Construído \\ Av. Osvaldo Aranha, 99 - 3o andar, Centro \\ Porto Alegre - RS - Brasil \\ CEP $90035-190$ \\ Telefone: +55 (51) 3308-4084 \\ Fax: +55 (51) 3308-4054 \\ www. seer. ufrgs. br/ ambienteconstruido \\ E-mail: ambienteconstruido@ufrgs.br
}

